\title{
PENGEMBANGAN BUDIDAYA HORTIKULTURA TANAMAN HIAS DI DESA SUKA MERIAH SIOSAR
}

\author{
Martina Restuati ${ }^{1 *}$, Ahmad Shafwan Pulungan ${ }^{1}$, Ani Sutiani², Nanda Pratiwi ${ }^{1}$, \\ Rahmad Gultom ${ }^{1}$
}

\author{
${ }^{1}$ Jurusan Biologi, Fakultas Matematika dan Ilmu Pengetahuan Alam, Universitas Negeri Medan, Medan \\ ${ }^{2}$ Jurusan Kimia, Fakultas Matematika dan Ilmu Pengetahuan Alam, Universitas Negeri Medan, Medan \\ Jl. Willem Iskandar Pasar V-Kotak Pos No. 1589 - Medan 20221 \\ *Penulis Korespodensi: t.restuati@gmail.com
}

\begin{abstract}
Abstrak
Upaya yang dilakukan pada kegiatan pengabdian ini adalah memberikan pelatihan bagaimana cara membudiyadaan tanaman hias hortikultural melalui empat tahapan: (1) pemamparan materi tentang gambaran umum tentang tanaman hias hortikultural, yang meliputi definisi tanaman hias, manfaat tanaman hias, langkah-langkah melaksanakan penanaman tanaman hias, (2) Penanaman tanaman hias, perawatan dan pengendalian hama (3) Pemanfaatan tanaman hias sebagai objek wisata, (4) review terhadap pelatihan yang telah dilaksanakan serta menarik kesimpulan. Kegiatan ini berlangsung dengan respon yang sangat baik dari para peserta agar kiranya dapat dipertimbangkan oleh pihak-pihak terkait. Mereka berharap agar kegiatan sejenis terus berlangsung tiap tahun, sekalipun dalam tema yang berbeda, akan tetapi adanya pertemuan antara warga dengan berbagai peneliti di bidang pendidikan, pelatihan dan Agrowisata menjadikan kegiatan ini sebagai sarana tukar pikiran untuk kemajuan Agrowisata.
\end{abstract}

Kata kunci: Anggrek, Agrowisata, Hortikultura, Tanaman Hias

\begin{abstract}
Efforts are being made on service activities is to provide training on how to cultured ornamental horticultural through four stages: (1) Material explaning on the general idea of the ornamental horticultural, which includes the definition of ornamental plants, the benefits of ornamental plants, steps in planting crops ornamental, (2) Planting ornamental plants, maintenance and pest control (3) Utilization of ornamental plants as a tourist attraction, (4) a review of the training that has been carried out and draw conclusions. This activity takes place with a very good response from the participants so that would be considered by the relevant parties. They hoped that similar activities continue to take place every year, albeit in a different theme, but the meeting between the residents with various researchers in the fields of education, training and Agro make this activity as a means of exchange of ideas for the advancement of agro tourism.
\end{abstract}

Keywords: Orchid, Agro Tourism, Horticulture, Ornamental Plants

\section{PENDAHULUAN}

Bencana alam meletusnya gunung Sinabung merupakan bencana yang membawa dampak trauma yang sangat berat bagi masyarakat yang terkena bencana, dan berpengaruh bagi kesehatan dan semangat kerja. Masyarakat memerlukan pendampingan untuk membangkitkan rasa percaya diri, keberanian dan semangat kerja mereka, Berdasarkan hasil pengamatan yang telah dilakukan ke daerah pemukiman, sebagian masyarakat cenderung hanya berdiam diri. Halaman rumah dan lahan yang diberikan kepada masyarakat masih belum dimanfaatkan secara maksimal demikian juga dengan seperangkat alat untuk membuat tanaman hidroponik belum semua dimanfaatkan masyarakat (Tarigan, A. 2016).

Daerah Karo adalah daerah pegunungan yang sangat potensiel untuk dijadikan areal pertanian terutama tanaman hortikultura baik untuk sayuran maupun tanaman hias. Berdasarkan hasil wawancara yang telah dilakukan kepada kepala desa Siosar diketahui bahwa total jumlah rumah yang direncanakan dibangun adalah 2.053 yang secara bertahap dilanjutkan tahun ini. Sedangkan jumlah pengungsi Sinabung yang rencana akan direlokasi sebanyak 1.700 kepala keluarga (KK). Masyarakat terdiri dari yang berada di dalam radius $3 \mathrm{~km}$ dari gunung Sinabung, yaitu yang bermukim di Kecamatan Payung (Desa Sukameriah) dan Kecamatan Naman 
Teran (Desa Bekerah, Desa Simacem), dan masyarakat yang tinggal di luar radius $3 \mathrm{~km}$ dari Kawah Gunung Sinabung dan berada di depan bukaan kawah, berpotensi terancam oleh guguran lava dan luncuran awan panas, yaitu: Kecamatan Payung (Desa Gurukinayan), Kecamatan Naman Teran (Desa Kutatonggal), Kecamatan Simpang Empat (Desa Berastepu dan Dusun Sibintun serta Desa Gamber). Sementara untuk lahan pertanian, telah disiapkan lahan di Siosar seluas 416 hektar Saat ini jumlah pengungsi korban erupsi Sinabung yang direlokasi sebanyak $370 \mathrm{KK}$. Terdiri dari $103 \mathrm{KK}$ warga Desa Bekerah, 136 KK warga Desa Sukameriah, dan 131 KK warga Desa Simacem. Masing-masing rumah sederhana dengan tipe 36 dibangun di lahan seluas 100 meter persegi dengan fasilitas satu ruang tidur, satu ruang utama, dan kamar mandi. Akses listrik, air, dan jalan sudah tersedia. Hal yang paling dibutuhkan dan paling memungkinkan dilakukan untuk kegiatan pengabdian masyarakat di Siosar ini adalah kegiatan pertanian yaitu mengembangkan usaha tanaman hias karena umumnya masyarakat pengungsi Siosar ini sebelum dipindahkan karena bencana adalah bertani, selain itu keadaan tanah siosar yang subur dingin dan tanah pegunungan sangat cocok untuk kegiatan ini. (Peraturan Daerah Kabupaten Karo Nomor 01 Tahun 2014)

Berdasarkan permasalahan yang ada maka usaha yang ditawarkan adalah melakukan kegiatan pengembangan pertanian dengan mengembangkan tanaman hias di lahan pekarangan rumah dan lahan pertanian yang sudah dimiliki masyarakat namun belum dimanfaatkan secara maksimal. Kegiatan ini akan dapat membantu masyarakat kembali bersemangat untuk bekerja kembali dengan bertani tanaman hias yang memiliki nilai ekonomis cukup tinggi dan dapat menghilangkan stress dan tauma akibat bencana bencana yang menimpa masyarakat. Selain itu kegiatan ini akan membantu untuk mewujudkan impian menjadikan Siosar menjadi daerah wisata yang mempesona.

Masyarakat Siosar sebagai masyarakat yang sudah terbiasa bertani tentulah sudah profesional yaitu memiliki kemampuan untuk menangkap permasalahan yang terjadi pada daerah mereka. Halaman rumah dan lahan yang diberikan kepada masyarakat masih belum dimanfaatkan secara maksimal demikian juga dengan seperangkat alat untuk membuat tanaman hidroponik belum semua dimanfaatkan masyarakat. Untuk itu kegiatan pengabdian masyakat ini bermaksud untuk melakukan kegiatan pengembangan pertanian dengan mengembangkan tanaman hias di lahan pekarangan rumah dan lahan pertanian yang sudah dimiliki masyarakata namun belum dimanfaatkan secara maksimal. Kegiatan ini akan dapat membantu masyarakat kembali bersemangat untuk bekerja kembali dengan bertani tanaman hias yang memiliki nilai ekonomis cukup tinggi. Selain itu kegiatan ini akan membantu untuk mewujudkan impian menjadikan Siosar menjadi daerah wisata yang mempesona.

\section{BAHAN DAN METODE}

Secara umum model mekanisme pada kegiatan ini adalah: tahapan pertama adalah melakukan observasi dan pembuatan Memorandum Of Agreement (MoA) dengan mitra. Kegiatan ini dilakukan dengan pendekatan sosialisasi dan metode pelatihan. Kegiatan ini meliputi beberapa tahapan-tahapan yang dilakukan dengan melihat permasalahan yang ada dimana para petani belum maksimalkan lahan pertanian dan perkarangan rumah yang ada secara maksimal. Upaya yang dilakukan adalah memberikan pelatihan bagaimana cara membudidayakan tanaman hias hortikultural melalui empat tahapan: (1) pemamparan materi tentang gambaran umum tentang tanaman hias hortikultural, yang meliputi definisi tanaman hias, manfaat tanaman hias, langkah-langkah melaksanakan penanaman tanaman hias, (2) Praktek Penanaman tanaman hias, perawatan dan pengendalian hama (3) Pemanfaatan tanaman hias sebagai objek wisata, (4) Pengkajian peluang wirausaha tanaman hias yang ditanam masyarakat. (5) review terhadap pelatihan yang telah dilaksanakan serta menarik kesimpulan. Dengan diberikannya pengetahuan dan pemahaman dalam melakukan budidaya tanaman hias akan menjadi bekal bagi para petani untuk pengembangan yang lebih maksimal.

\section{HASIL DAN PEMBAHASAN}

Masyarakat Siosar sebagai masyarakat yang sudah terbiasa bertani tentulah profesional memiliki kemampuan untuk menangkap permasalahan yang terjadi pada daerah mereka. Halaman rumah dan lahan yang diberikan kepada masyarakat telah dimanfaatkan secara maksimal hanya saja seperangkat alat untuk membuat tanaman hidroponik belum semua dimanfaatkan masyarakat.

Mengingat cukup besar potensi para petani di Siosar dalam membudidayakan pertanian khususnya tanaman hias hortikultural diperlukan suatu upaya untuk meningkatkan pengetahuan petani tersebut. Upaya yang dilakukan adalah memberikan pelatihan bagaimana cara membudiyadaan tanaman hias hortikultural melalui empat tahapan: (1) pemamparan materi tentang gambaran umum tentang tanaman hias hortikultural, yang meliputi definisi tanaman hias, manfaat tanaman hias, langkah-langkah melaksanakan penanaman tanaman hias, (2) Penanaman tanaman hias, perawatan dan pengendalian hama (3) Pemanfaatan tanaman hias sebagai objek wisata. (4) Pengkajian peluang wirausaha tanaman hias yang ditanam masyarakat. (5) Review terhadap pelatihan yang telah dilaksanakan serta menarik kesimpulan. Dengan diberikannya pengetahuan dan pemahaman dalam melakukan budidaya tanaman hias akan menjadi bekal bagi para petani untuk pengembangan yang lebih maksimal. Kegiatan ini akan dapat membantu masyarakat kembali bersemangat untuk bekerja kembali dengan bertani tanaman hias yang memiliki nilai ekonomis cukup tinggi, kepada peserta juga dijelaskan secara menghitung nilai jual bunga hias yang mereka tanam. Selain itu kegiatan ini akan membantu untuk mewujudkan impian menjadikan 
Siosar menjadi daerah wisata yang mempesona. Berikut adalah proses Aplikasi pada kegiatan pengabdian kepada masyarakat "Pengembangan Budidaya Hortikultura Tanaman Hias di Desa Suka Meriah Siosar".
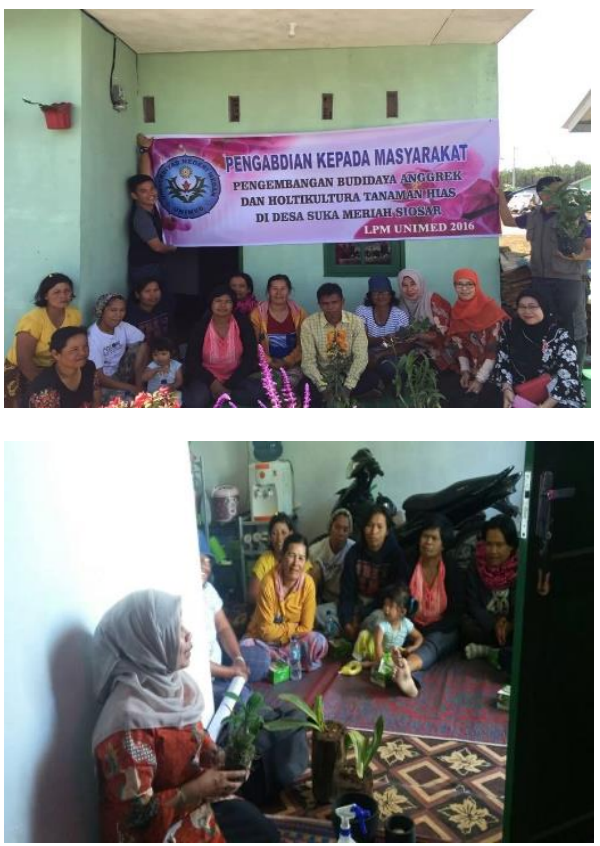

Gambar 1. Pemaparan Instruktur Tentang Pengembangan Tanaman Hias

Rangkaian dalam kegiatan pendalaman materi ini berlangsung selama satu hari yang diikuti para peserta kegiatan. Penyampaian materi ini dirasa perlu guna menyegarkan kembali ingatan para warga terhadap cara pengembangan tanaman hias.
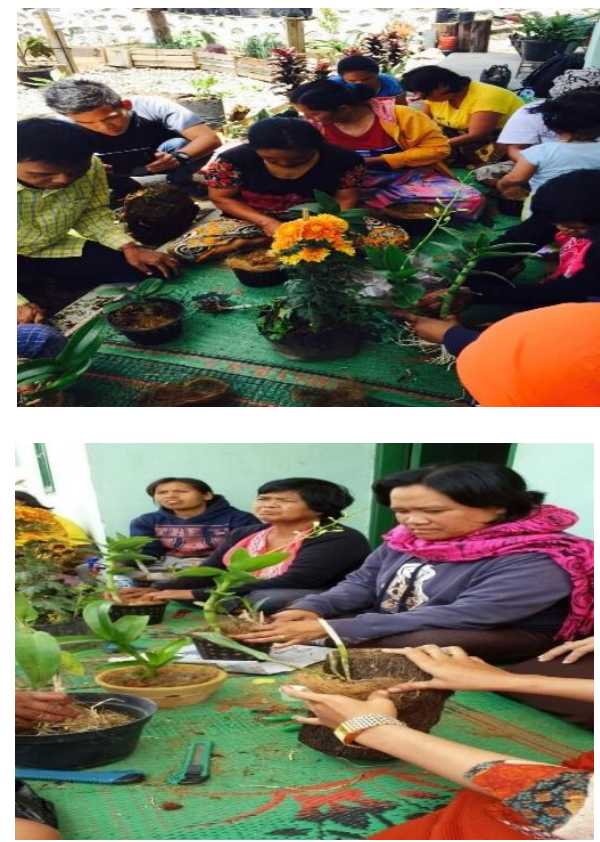

Gambar 2. Penanaman Tanaman Hias

Setelah dilakukanya pemaparan gambaran umum tanaman hias warga diajak untuk melakukan penanaman langsung tanaman hias, perawatan dan pengendalian hama. Hal ini bertujuan untuk mengajak mesyarakat praktek langsung cara menanam tanaman hias yang sudah disampaikan saat pemberian materi. Sehingga masyarakat lebih lebih matang dalam pemahaman bertanam hias.

Tahapan selanjutnya dari proses pelaksanaan kegiatan pada pengabdian kegiatan masyarakat di Desa Suka Meriah Siosar Karo tahun 2016 adalah, seluruh peserta diarahkan kembali ke rumah masingmasing untuk membudidayakan lebih lanjut tanaman hias yang sudah dipaparkan dan diberikan kepada masing masing warga. Pada proses ini, dilakukan pendampingan mulai dari penanaman, perawatan dan cara pengendalian hama. Pendampingan dilakukan dengan bertemu langsung, juga dengan komunikasi melalui telepon seluler dan email. Hal ini dilakukan, karena keterbatasan waktu para peserta jika harus dikumpulkan kembali tiap minggunya, maka berdasarkan permasalahan tersebut diambilah kebijakan bahwa pendampingan dapat juga dilayani via telepon dan email. Kegiatan selanjutnya adalah pendampingan sekaligus evaluasi mereview terhadap pelatihan yang sudah dilaksanakan.

Kegiatan yang telah berlangsung kurang lebih 6 (enam) bulan di Desa Suka Meriah Siosar yang melibatkan warga yang berjumlah 15 orang, memiliki berbagai dampak yang dirasakan oleh para instruktur serta para peserta. Dampak kegiatan bias berupa dampak langsung yang dirasakan oleh peserta serta dampak tidak langsung.

Bagi para instruktur, kegiatan ini merupakan bagian dari tri dharma perguruan tinggi yaitu pengabdian kepada masyarakat. Dosen sebagai salah satu komponen strategis bangsa juga memiliki peran dalam meningkatkan kualitas pendidikan, keterampilan warga di tanah air. Selain penelitian yang dilakukan oleh para dosen tersebut, aplikasi dari penelitian tersebut berupa kegiatan dalam bentuk pengabdian masyarakat. Bentuk pengabdian ini adalah hasil dari penelitian yang telah dilakukan para dosen sebelumnya. Sehingga, semua materi yang disampaikan merupakan hasil ilmiah dari pemikirian ilmiah para peneliti.

Selain itu, dampak lainnya yang di dapat dari kegiatan ini bagi para dosen adalah juga sebagai wujud dan peran serta dengan membawa nama Universitas Negeri Medan ke tengah-tengah masyarakat agar semakin dikenal dan dirasakan manfaatnya. Salah satu strategi dalam memperkenalkan institusi bagi dunia luar kampus adalah dengan melalui kegiatan pengabdian masyarakat, karena kegiatan ini langsung berhadapan dengan masyarakat sasaran.

Bagi para peserta pelatihan, dampak yang dirasakan adalah diperolehnya kembali pengetahuan yang sudah terlupa. Model diskusi yang dilakukan kepada para peserta menjadikan peserta bukan sebagai bawahan, akan tetapi sebagai rekan sejawat yang dalam aplikasinya sangat mudah untuk diterima oleh para peserta. Dari hasil wawancara kepada para peserta, didapat bahwa mereka sangat senang dengan pola pelatihan seperti ini. Ilmu yang mereka dapat langsung diaplikasikan atau dipraktekkan di rumah 
mereka, sehingga serapan ilmu sangat tinggi. Harapan mereka adalah, kegiatan ini tetap berlangsung secara berkesinambungan, bahkan mereka berpesan agar pintu diskusi dapat tetap dibuka kapanpun dan dimanapun, sehingga ada tempat bertanya.

Tolak ukur keberhasilan suatu kegiatan dalam pelatihan adalah pengukuran seberapa jauh efektifitas kegiatan tersebut. Efektifitas kegiatan ini dapat dilihat dari seberapa jauh peserta mendapat pengalaman baru dan seberapa banyak pengalaman tersebut dapat diserap dan diaplikasikan serta seberapa jauh pengalaman tersebut dapat dibagi kepada orang lain. Salah satu fakta yang bisa menjadi gambaran kenapa mengukur efektivitas pelatihan sangat penting adalah seberapa jauh biaya yang dikeluarkan untuk menyelenggarakan sebuah program pelatihan bagi warga. Dalam hal ini pengeluaran untuk pelatihan merupakan sebuah bentuk investasi pendidikan dimana lokasi mitra berharap di masa yang akan datang ada keuntungan yang bisa diambil seperti kualitas pendidikan dan keterampilan warga yang meningkat. Sebagai contohnya diharapkan setelah dilaksanakan pelatihan, warga bisa langsung menerapkan ilmu barunya untuk kemajuan pendidikan dan pembelajaran sehingga otomatis desa mitra akan meningkat. Dengan jumlah peserta yang hanya berjumlah 15 orang, diharapkan seluruh peserta tersebut mengamalkan serta membagi ilmu yang didapat mereka kepada warga yang lain. Efektifitas dalam pelatihan ini dapat diukur dalam tiga hal yang merupakan komponen penting dalam kegiatan ini.

1. Penilaian sebelum pelatihan

Penilaian sebelum pelatihan berarti mengambil data dan merumuskan masalah mendasar yang dihadapi para warga dalam membudidaya Anggrek dan tanaman hias hortikultura. Proses ini memerlukan observasi ke daerah sasaran sehingga didapat nantinya permasalahan utama yang bersifat dasar bagi para warga. Permasalahan yang diulas dalam kegiatan ini adalah cara pembudidayaan yang baik sehingga lanjutanya dapat dipasarkan bahkan menjadi objek wisata di kawasan Siosar.

2. Monitoring pelaksanaan

Fase kedua dalam metode penilaian efektivitas pelatihan adalah monitoring atau pengawasan pelaksanaan program training. Dari pengamatan ini akan bisa diketahui apakah kegiatan pelatihan yang sedang dilaksanakan bisa dimengerti dengan baik oleh peserta atau tidak, apakah peserta mengikuti program training dengan antusias atau tidak, keaktifan peserta selama proses pelatihan berlangsung, serta mengetahui kemampuan peserta sebelum dan sesudah pelatihan apakah mengalami peningkatan atau tidak. Hasilnya adalah para peserta antusias dalam setiap sesi yang diberika. Aktifitas dikusi berlangsung baik dengan mengemukakan berbagai permasalahan dalam aplikasi penanaman tanaman hias. Di akhir kegiatan, dilakukan Tanya jawab, para peserta mampu mengulang kembali berbagai materi yang telah diberikan sebelumnya.
3. Monitoring efektivitas pelatihan

Efektifitas berikutnya yang dapat dilihat adalah hasil dari pelatihan yang dalam hal ini dikumpulkan dalam bentuk tanaman hias yang baru. Melalui hasil tanam yang baik dapat dilihat, bahwa materi dan pendampingan yang telah diberikan dan lakukan mampu diserap oleh para warga sebagai peserta pelatihan.

\section{KESIMPULAN DAN REKOMENDASI}

Kegiatan pengabdian kepada masyarakat yang telah berlangsung di Desa Suka Meriah Siosar di tahun 2016 ini perlu mendapat perhatian dari pihak Universitas Negeri Medan maupun pihak pemerintahan Kabupaten Karo. Diperlukan suatu dokumen tertulis yang dapat digunakan kedua belah pihak dengan tujuan memajukan keterampilan dan keahlian dalam budidaya taman Anggrek dan Hortikultura. Dokumen tersebut seperti pernyataan kesepahaman (MoA) antara Universitas Negeri Medan dengan Pemerintah Kabupaten Karo khusus dalam bidang pendidikan, pelatihan, Agrowisata sehingga nantinya jika ada kegiatan-kegiatan sejenis, dapat diarahkan langsung ke Kabupaten Karo

Rekomendasi lain adalah tindak lanjut dari kegiatan in dimasa `yang akan datang, agar kiranya jika terdapat kegiatan sejenis dapat langsung diarahkan tanpa harus memilih lagi kabupaten sasaran untuk lokasi pengabdian kepada masyarakat. Hal ini diperlukan agar adanya kesepahaman dan sejalan dengan rencana kegiatan tahun akan datang yang telah disusun diatas. Catatan penting selama kegiatan ini berlangsung adalah respon yang sangat baik dari para peserta agar kiranya dapat dipertimbangkan oleh pihak-pihak terkait. Mereka berharap agar kegiatan sejenis terus berlangsung tiap tahun, sekalipun dalam tema yang berbeda, akan tetapi adanya pertemuan antara warga dengan berbagai peneliti di bidang pendidikan, pelatihan dan Agrowisata menjadikan kegiatan ini sebagai sarana tukar pikiran untuk kemajuan Agrowisata.

\section{UCAPAN TERIMA KASIH}

Terima kasih kepada DIPA BOPTN Universitas Negeri Medan Sesuai Surat Pengesahan Daftar Isian Pelaksanaan Anggaran Unimed Tahun Anggaran 2016 Nomor: 00487/UN33/KEP/KU/2016 Tanggal 10 Maret 2016, telah membiayai pengabdian ini.

\section{DAFTAR PUSTAKA}

Blue. F. 2014. Makalah Prakarya Budidaya Tanaman Hias. http:// blogsimpleuntukpelajar. blogspot.co.id. diakses tanggal 12 Desember 2015.

Dahnial, Iwan. 2008. Aneka Tanaman Bonsai. Tersedia dalam http://iwandahnial. wordpress.com/2008/06/17/aneka-tanamanbonsai/, diakses tanggal 12 Desember 2015. 
Loegman, Agoes. 2010. Erupsi lima Gunung api. Jakarta. Bulletin Vulkanologi dan Bencana Geologi.

Peraturan Daerah Kabupaten Karo Nomor 01 Tahun 2014 Tentang Perubahan Atas Peraturan Daerah Kabupaten Karo Nomor 19 Tahun 2008 Tentang Orgaanisasi Dan Tata Kerja Lembaga Teknis Daearah Kabupaten Karo.

Tarigan, Agustoni, 2016. Evaluasi kesesuaian lahan kentang di kawasan relokasi siosar kabupaten karo. Medan. Fakultas Pertanian USU

Wikipedia. 2011. Budidaya dan Perawatan Tanaman Bonsai. Tersedia dalam: http://en.wikipedia.org/wiki/Bonsai_cultivation _and_care, diakses pada tanggal 12 Desember 2015. 